\title{
REVITALISING THE OLD INDUSTRIAL MOVE ALONG DANUBE WATERFRONT
}

\author{
DOI: 10.18485/arh_pt.2020.7.ch44
}

\author{
_ Milena Vukmirovic \\ PhD, Assistant Professor, University of Belgrade - Faculty of Forestry, \\ Department of Landscape Architecture and Horticulture, 1 Kneza \\ Viselava Street, 11000 Belgrade, milena.vukmirovic@sfb.bg.ac.rs
}

\section{_ Marko Nikolic}

PhD, Assistant Professor, University of Belgrade - Faculty of Architecture,

73/II Blvd. Kralja Aleksandra, 11000 Belgrade, marko@arh.bg.ac.rs

\begin{abstract}
The purpose of this paper is in presenting the new approach in revitalisation of the old industrial move along the Danube waterfront in Belgrade, based on the active participation of different stakeholders in design process. Special attention of the work is placed on the actual state of the industrial heritage buildings and sites at the former Danube Industrial Zone and the design process of the future Belgrade Linear Park. The main objective of this process is in preservation and use of the potential of this territory, in order to make a new gathering place and establish a direct connection of the city with its rivers.
\end{abstract}

KEYWORDS _ industrial heritage, old railway, Danube Waterfront, Belgrade Linear Park

\section{INTRODUCTION}

Until recently, Belgrade's riverfront has been characterized by devastated industrial zones and public promenades that are in poor condition. However, several mega-projects such as Belgrade Waterfront project, K-District or Belgrade Gondola, that were initiated in the last two decades are seen as a power to completely change this situation. Having in mind that these mega-projects are developed in a socio-political context characterized by insufficiently established neoliberal discourse, public institutions and democratic culture, there were fears that this would affect the preservation of the industrial heritage, but also the identity of Belgrade in general. Considering the mentioned situation, the aim of this paper is point out actual experiences related to the process of revitalisation of the old industrial trail along the Danube waterfront, also known as Slaughterhouse lane, which points to some progress in the urban planning process and the preservation of the industrial heritage sites. Industrial heritage includes all tangible and intangible evidence; document structures, human settlements, as well as the nature and the built environment related to industrial processes, starting from the second half of the 18th century to the present day, while not neglecting earlier roots in the pre-industrial era. It is concluded that industrial heritage has great social value, as an important evidence about the life of ordinary people and their identity. Also, it has a technological and scientific value in relation to the history of manufacturing, engineering and construction, as well as a significant aesthetic value in relation to its architecture, design and planning. These values are related to only industrial heritage, its materials, components, equipment and method of installation in industrial environments, as well as written documentation and intangible records related to the memory of the people and customs. 
When it comes to protection and preservation of the industrial heritage, Republic of Serbia cannot be really taken as a prosperous model. Common problem of the State is lack of recognition for the importance of cultural and industrial heritage and absence of clearly defined cultural policy which would enable stimulating atmosphere for dealing with the latter (Vukmirovic \& Nikolic, 2021). In favour of that also goes the fact that there are not enough competent and skilled people which could be the driving force for treating this problem, so as absence of intersectoral partnership and cooperation between the relevant institutions, organizations and bodies. The issue goes further as there is no recognition of industrial heritage as a substantial segment of cultural heritage and a part of cultural identity which possesses large development potential.

The issue concerning the preservation of industrial heritage in Serbia also include its instrumentalization by investors' urbanism. Interpreting the recommendations ${ }^{1}$ in a peculiar way, entrepreneurs often use the term industrial to promote a location, even when there are no industry traces left on the site. This is in line with the urban renewal strategies in which the heritage is increasingly used as a driver of renewal and a tool for attracting investment. Accordingly, heritage in general, and even industrial, has in recent decades become not only the basis for promoting the memory of the industrial past, but also a marketing tool in urban renewal, used to successfully sell restored spaces (Cizler, 2016). Market-led development is often a threat to public spaces and to heritage, which also characterises the situation in Serbia, especially in Belgrade where several mega projects are being implemented. In regards with this, entire parts of city in the near vicinity of the Belgrade city centre are owned and developed by the private sector and new projects are being built on them ${ }^{2}$, based almost exclusively on high-value apartments and offices for large firms, located at the industrial heritage sites. The spaces created in this way could also threaten democratic control of space, local context and activities, and one of the main consequences is the lack of public spaces. That lead to the question of the ways to deal with heritage protection when cities are so heavily influenced and so dependent on the market. On the other side, the lack of greater public and civil sector involvement often results in a lack of non-commercial and public spaces in the city.

Other issues are related to the situation that the preservation of industrial architecture in Serbia is often compromised by a lack of appreciation of their values. Because most of this buildings and sites date from the 18th to the 20th century, sometimes, they are not regarded as sufficiently old to focus the attention of either conservation experts or citizens and users. They don't understand that the buildings which represent their everyday environment actually possess the values and characteristics of monuments. For that reason, industrial heritage sites are exposed to degradation processes, they are neglected and left to decay. Even though same efforts are taken in Serbia to find a more adequate conservationist approach, to modernise the legal and administrative systems, to integrate conservation into the planning process, and to achieve greater co-operation between the protection service and urban planning, it is becoming more and more difficult to protect the endangered urban heritage, while the preservation of its authenticity and integrity is becoming a prime professional task. Although the conservation of cultural heritage has been integrated into the laws, planning process and master plans, such in Belgrade, aiming to involve a large number of stakeholders and citizens, in the practice we can see many problems and inconsistencies in implementation those goals.

\footnotetext{
1 The Council of Europe Recommendation R (87) 24 on European Industrial Towns states that the disadvantages of industrial cities and regions should be turned into assets and opportunities, particularly through the re-use and redevelopment of public services and infrastructure and the mobilization of existing human resources; that the wealth of the historical and architectural heritage of industrial cities and regions should be rehabilitated so as to constitute a considerable source and potential for future development; have amassed a wealth of experience and have the potential to promote and respond to innovation and new challenges; and that industrial renewal policies should, wherever possible, be based on a change of function and the revitalization of existing facilities.

2 Such as Belgrade Waterfront and other projects that will be presented and discussed in the next sections of the paper.
} 
In order to achieve stated objective, the research covered different phases that will be presented in this paper. The first phase dealt with short overview of the actual socio-political context started after the political changes at the beginning of 2000 and its planning procedures related to the industrial heritage protection in Serbia. Next part of the research has focused on the study of the site along the Slaughterhouse lane in order to present its origins, development and transformation initiatives related to the actual Belgrade Line park project, taking into the consideration participative practices and co-creation procedures which are implemented within this project.

\section{HISTORIC BACKGROUND}

The close relationship between the two rivers, the Sava and Danube, and the city is one of the main elements of Belgrade's specific historical and cultural identity, authentic urban morphology and special cityscape characteristics. The modern urban development of Belgrade in the early 19th century, after the establishment of The Serbian Principality and its partial political autonomy within the Ottoman Empire, is connected with the rapid development of trade and river traffic and the establishment of the first manufacturing workshops.

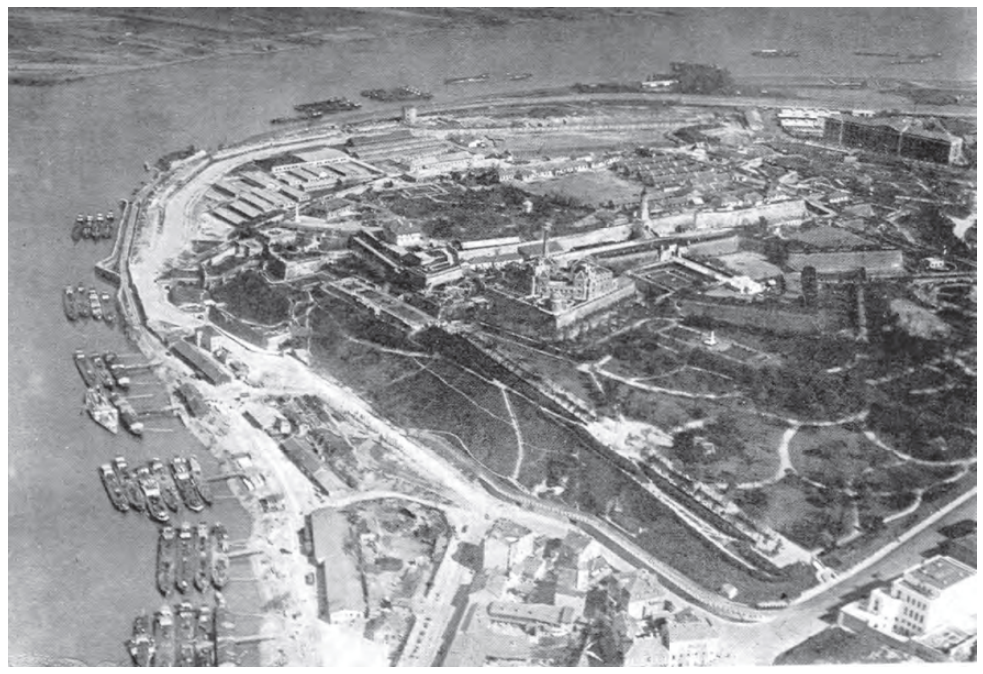

_ Figure 1: Belgrade and its industrial sites along the waterfront in 1936

The economic centre of the city was in the area of the Sava Port, as the main connection of Belgrade and Serbia with the Austrian Monarchy and Europe. There, developed a new trade and transit district and trading houses, hotels and warehouses were built. It displayed the new European spirit, liberation and modernisation and many foreign travellers left testimonials that area was very colourful and vivid. After the proclamation of the Kingdom of Serbia in 1882, stronger ties with Europe were established, especially with the Austro-Hungarian Monarchy. Foreign capital arrived in Serbia, the first industrial factories were built and the state experienced constant economic growth. This was especially supported by the construction of the railway (1881-84) and the first railway bridge over the Sava River. The railway had a crucial impact on Serbia's future development and Belgrade became a link between Europe and Sofia and Istanbul. The greatest changes were made around the Sava River's right bank, where the Railway Station was built in 1884 which today stands as proof of the technical and architectural development of Serbia.

The expansion of the city toward the riverbank was planned, with a new structure with square blocks covering the area between the railway station and the riverbank, as recorded on the Bešlić plan from 
1898. However, this has not been realized and today this area is a part of the Belgrade Waterfront project. New industrial complexes were built on the south-west entrance to the city, at Mostar, near the Sava River and the railway bridge, and on Palilula, near the Danube River. The attractiveness of the Danube area was as a result of the railway connection, the easy supply of water and wastewater discharge, and the vacant, undeveloped land.

On the Danube Riverbank area (near Pančevo Bridge) the First Industrial Slaughterhouse was built in 1895 and has recently been in the process of valuation as a cultural property with preventive protection. The railway, parallel to the riverbank was built in 1898-99, and linked the new industrial area on the Danube with the Railway Bridge on the Sava, cutting the connection time between the town and the rivers (Nikolić and Roter Blagojević 2018.)

\section{Danube industrial zone}

Danube industrial zone has been developed in the area stretching from Dorćol to the present-day Pančevo Bridge and further on towards Karaburma. The attractiveness of the area depended on transportation advantages, an example supplies of water, wastewater discharge on vacant undeveloped land, and the proximity of the municipal power station built near the Danube in 1892. Moreover, this was the first industrial zone connected to the railway system, which was a considerable boost to its further development. Among other buildings it includes following objects and sites that are of great importance for this research: one-track railway known as Klanička pruga, old textile factory (BEKO), "The power and light" thermal power station and Kosta Sonda's Confectionery Factory. Belgrade textile factory building was built in 1931. It is a complex under previous protection. It is located in the area named as Danube industrial zone and belongs to the complex of Belgrade Fortress with its protection as cultural monument of outstanding value. This fact is of great importance, because all discussions related to this area starts and ends with it. Today, this complex has been largely demolished and a new complex has been built for exclusive housing and business centre. The "Power and Light" Thermal Power Station, a cultural monument, was built from 1930 to 1932, according to a project by the Swiss Society for Electrification and Transport from Basel. The complex consists of a Power Plant building, a crane, a pumping station and a filter plant. This industrial complex is one of the most significant parts of the interwar period, with a distinct Bauhaus style influence in its design. In addition to the architectural values, the complex can be noted significant technical achievements related to AC power. The buildings are in very poor condition today, they are abandoned and in ruins. Within the complex there are remains of machinery and other machine plants. (Nikolić, Drobnjak and Kuletin Ćulafić 2020.) The former Kosta Sonda's Confectionery Factory has now been renovated and revitalized into a hotel Mona.

Ten years after the Central railway station was commissioned, construction of a slaughterhouse on the Danube began. The one-track railway known as Klanička pruga, which was commissioned in 1899, ran from the Main railway station along the coast of the Sava River, ran through the dock along the Sava quay in front of buildings with storerooms and shops, and continued around the Lower Town and across Jalija to the Slaughterhouse. The Klanica railway station (later the Danube station) was also opened on this line, which, received new tracks over time. The gorge was a "blind track" until the construction of the Pančevo Bridge, when it continued across the river to Banat. In the interwar period, the railway grew into an industrial railway to serve the Danube industrial zone. Altogether, the Belgrade train system was modest, but due to running railroads parallel to the Sava and Danube rivers, it made it difficult enough for future urban development (Vuksanović-Macura, 2015; Mihajlov, 2011).

Considering the Belgrade one-track railway - Klanicka pruga, there is currently no valid plan for the entire railway line, except that a decision was made in 2018 to create a detailed regulation plan for the line park. That plan will deal with the future transformation of this space into a large urban linear park that will be used as a connection of the city to its waterfront. 


\section{PLANNING CONTEXT IN BELGRADE}

Citizens' participation in the process of drafting and approving planning documents is defined in the Rulebook on contents, method and procedure of plan documents adopted in 2011 and which is harmonised with the Construction Planning Law many times as it has changed and improved. Thus, the Principle of Participation of Participants in the Spatial and Urban Planning Process is provided by the public insight. Since December 2014, public insight takes place in two phases, before drafting the planning document as an early public inspection and a public insight of the draft planning document. During these procedures, all interested citizens, institutions, companies, organizations and other participants can send its comment, while the information on public insights into the planning documents is posted in the Central Register of Planning Documents.

This is important to note because although more was expected after the democratic changes that took place after 2000 , this is the maximum participation that has been achieved so far. Many authors ${ }^{3}$ have written about this issue, trying to determine the causes of this condition. In general, the transformation that took place in the 2000s was characterized as "proto-democracy" (Vujošević, 2010), which meant "in terms of economic orientation, the tendency to implement the principles of the neo-liberal paradigm have never been stronger, which, together with the lack of institutional capacity, makes Serbia a transitional society even in the second decade of the 21 st century" (Peric $\&$ Miljus, 2017). In such circumstances of the market-based economic system, planners are left unable to understand the complexity of the altered socio-economic framework (Maruna, 2015; Peric \& Miljus, 2017), while the involvement of different actors could be characterised as freedom manifested only 'on paper' - the voice of stakeholders other than the ruling government bodies can be expressed, but reaction to it is constantly missing (Maruna, 2015; Cvetinović, et al., 2017; Peric \& Miljus, 2017). According to Perić (2016), the present situation is characterised a close relationship of the highest government bodies with foreign investors in which only experts close to governance structures could be heard in the planning process and their influence on decision-making is, however, limited. On the other side, "civil sector and non-governmental organizations try to advocate the public interest; when it comes to great spatial development challenges, they are mainly not capable of such activity" (Cvetinović, et al., 2017; Peric \& Miljus, 2017).

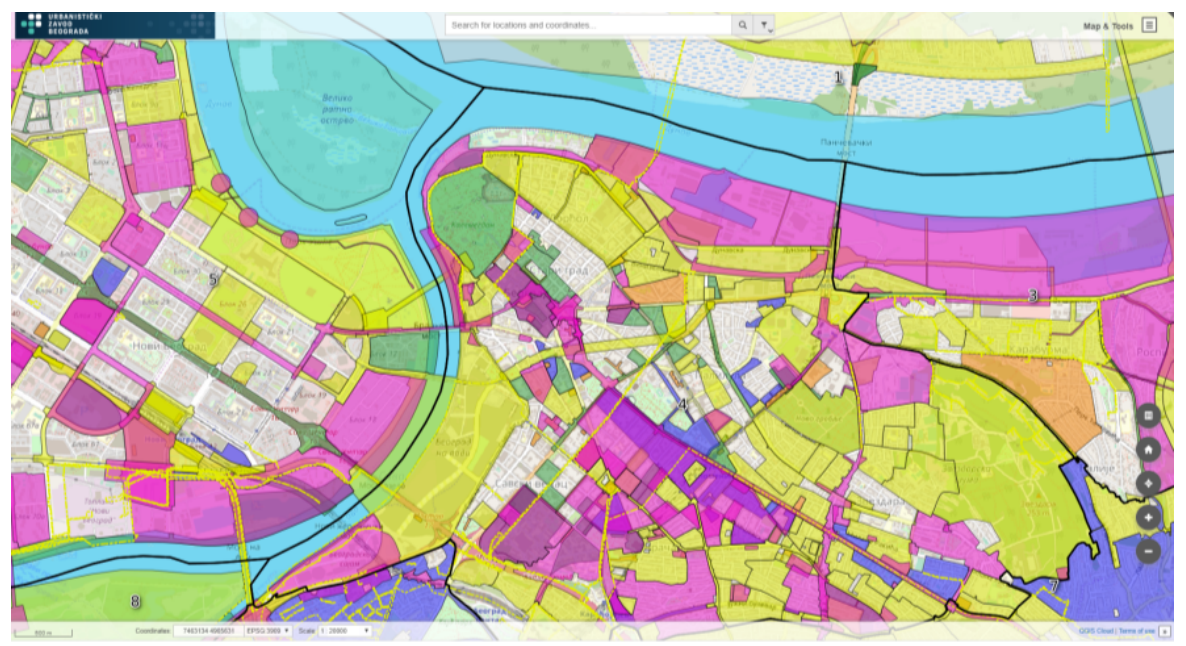

_ Figure 2: Overview of current urban plans for the City of Belgrade. Belgrade Urban Planning Institute 2020 
If the presented situation is viewed in relation to the Arstein's Ladder of citizen participation, it could be estimated as tokenism - "pseudo-participation" with the most common approach related to information, while consultations and placation occur mainly as isolated cases. According to Sokolova (2006) "new communication tools are to be used as channels for participation and consultations from the citizenry", which "meant not just relying on one specific tool, such as using the Internet and wireless technologies, but including television, radio and whatever tools might work to facilitate the process". Publishing online legislation, legislation proposals and other public documents can be seen as a beginning of the citizen involvement into the process, but it is still very much a top down approach by government. Groups and individuals engaged in e-democracy mainly rely on the agenda set by government and react to what government is doing to create input (Riley \& Gilbert Riley, 2003), but "at the same time there are individuals and organizations outside governments engaged in recruiting "minipublics" or in developing online communities of e-democracy participants" (Sokolova, 2006).

Considering all the mentioned, the next part of the paper will present the actual state of the mentioned heritage sites and particular civil initiatives related to its revival. This applies in particular to the perceived fact that, with regard to the treatment of industrial heritage and its future function, institutions and professional bodies dealing with heritage protection are exclusively consulted.

Slaughterhouse lane

In his paper titled Rise and Decline of the Sava Slope, Dajč (2012) shows the railroad that connected the train station to the slaughterhouse and later to other territories via the Pančevo Bridge as one of the key causes of coastal decline. Although the 1972 General urban plan foresees the removal of this railway line and the relocation of the train station, with the aim of bringing Belgrade to its rivers, this topic seriously began to be discussed and work on at the end of 2018 and the beginning of 2019. In April 2019, it was announced in the media (Mučibabić, 2019) that the New York architectural studio "Diller Scofidio and Renfra", who worked on the project for the High Line in New York, was invited to submit a proposal for a move that extends from the Concrete Hall to the Pančevo Bridge, which is planned to be transformed into a park. In the same period, they took a two-day visit to the site for this occasion and gave the initial concept of transforming the move. However, the fee for hiring a world-renowned team turned out to be extremely high, which led to the idea of a different approach. All of the above was preceded by a decision of the City of Belgrade Assembly (September 2018), by which the Directorate for Construction Land and Construction of Belgrade initiated the development of a Detailed Regulation Plan (PDR) for this area, which covers the area of the section of the old railway line from the Concrete Hall to the Pančevo Bridge, $4600 \mathrm{~m}$ long. The Urban Planning Institute of Belgrade has been engaged in the work of drafting the plan.

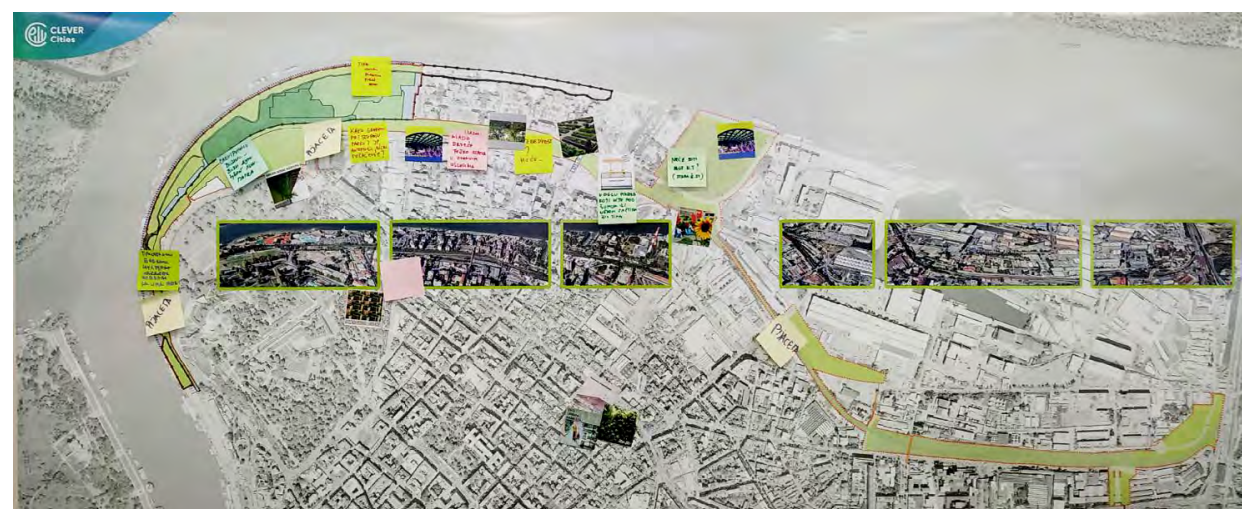

_ Figure 3: Linear park, content analysis. Source: Clever Cities, Bellab

The change in approach coincided with the stage of the process in which the initial concept and pro- 
gram needed to be defined and the beginning of the realization of an international scientific project Clever City. The theme of Clever City 4 project is co-creation in city planning, using live lab approaches and nature-inspired solutions. Thus, the team working on the project together with the team of the Urban Planning Institute devised a methodology for developing a plan that aimed to involve all stakeholders. For this purpose, the Urban Innovation Partnership ${ }^{5}$ has been set up, bringing together about 50 participants from different institutions, from over 35 local and national public and private sector institutions, academia and civil society, that seek through focus group discussions. Members of this Partnership pursue to jointly define their needs and wants, but also consider the constraints and obstacles to their realization ways to overcome them.
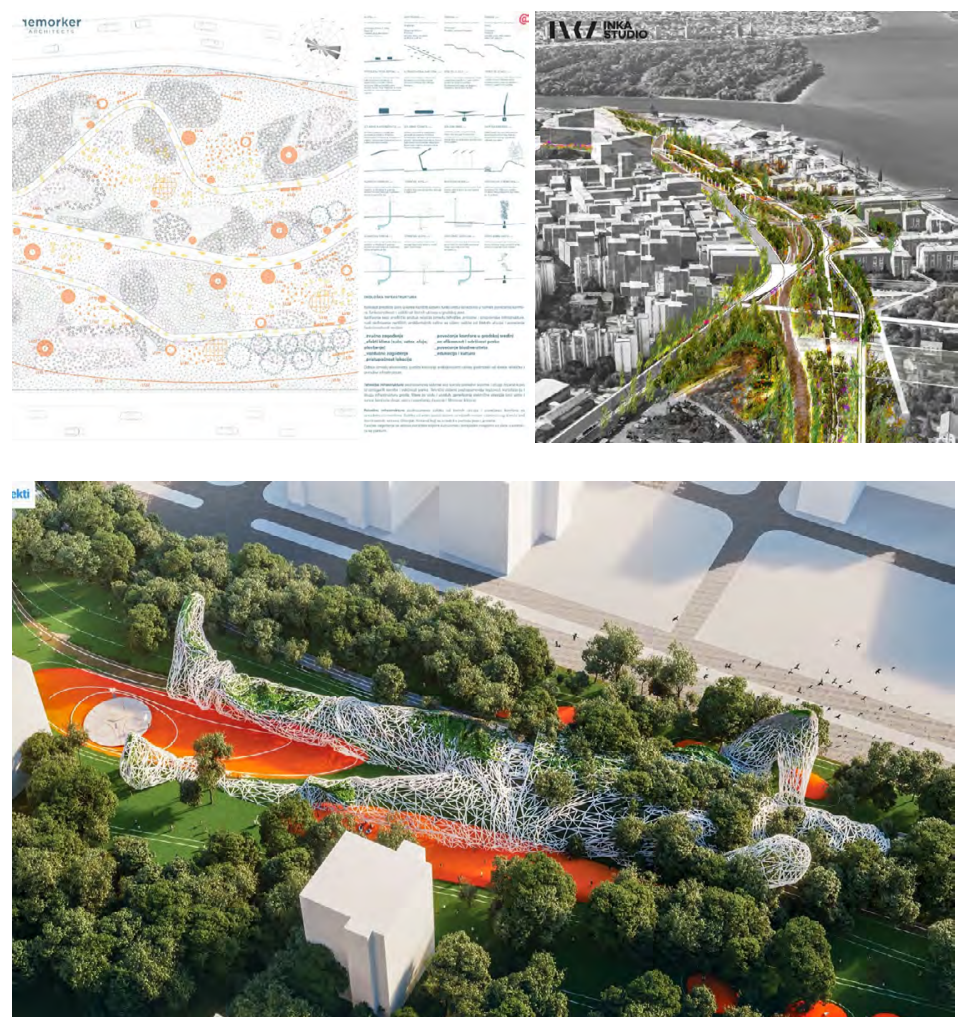

_ Figure 4: Belgrade Linear Park - 3 of 10 winning proposals: Remorker studio, INKA studio, team Vukmirović, Vujović, Copić, Radić

The first two Partnership meetings were held to prepare a competition for young architects who should propose a new look and function for the future Line Park. Thus, at the first meeting, it resulted

4 The Project aim to increase and improve local knowledge of nature-based solutions, demonstrate that greener cities work better for people and communities, contribute data and information to EU policymaking, and ultimately promote and enable the uptake of nature-based solutions in urban planning world-wide. It is conducted in partnership with cities that encompass Hamburg, London and Milan as front runner cities, and Belgrade, Larissa, Madrid, Malmö, Sfântu Gheorghe and Quito. https://clevercities. eu/the-project/

5 The Partnership was formalized by the Mayor's decision form 29th November 2019, but it does not represent the final and closed set of members, but is the basis for a broad, holistic co-creation process in urban development planning. http://bellab.rs/partnerstvo/ 
in an initial interactive mapping of needs, wants and the first proposals for nature-inspired solutions for the Line Park space at Dorcol. Motivated participants suggested a number of quality and creative ideas, including the introduction of urban beekeeping, the sounds of nature in GSP electric vehicles, air pollution alarms in the form of badges, and the integration of nature-inspired solutions into medieval and industrial architectural heritage (Centar za eksperimente i urbane studije, 2019). The second meeting, held in December 2019 on the basis of co-creation, defined the vision of the Line Park 2025 as an attractive, self-sustaining, multifunctional, eco-technological, artistic, educational and research demonstration ground that promotes healthy living, community, cosmopolitanism through national culture, nature protection and youth empowerment (Centar za eksperimente i urbane studije, 2019).

In the same period, an online questionnaire for interested citizens was published as well as a competition for young architects. During the same period, an online questionnaire for interested citizens was published, as well as a competition for young architects who had insight into both the Partnership reports and the survey results, on the basis of which they were able to define their Line park design proposals. As of February 2020, 571 respondents answered their questions. Among the proposed amenities to be found in the park, citizens cited a music pavilion, an acoustic playground, an amphitheatre (for dance and theatre events), commercial facilities (coffee shop, restaurant, catering facilities), a network of observation points, a green creative corridor, a centre for applied physics, eco-educational centre, corner for socializing and board games, city orchard with community checkpoints, sports fields, skate park, adventure park, outdoor gym, etc. The above contents, as well as the strip, as a preliminary purpose of this space, influenced the character of the 28 proposed solutions, among which 10 were selected, whose teams will further elaborate and design individual segments of the location.

Further activities will include the development of conceptual solutions for the arrangement of the line park, which will be carried out simultaneously with the drafting of a detailed regulation plan for this area. Drafting and public access to the draft plan will be organized according to the established procedure, which is expected in the coming months. At the same time, the City is negotiating with potential project funders, more specifically, investors interested in investing in locations in the immediate area (Belgrade Port, K-District, Marina Dorćol, etc.).

_ Table 1: Review of the main characteristics of the industrial heritage buildings on the Danube Waterfront

\begin{tabular}{|c|c|c|c|c|}
\hline Location & $\begin{array}{l}\text { Heritage site of } \\
\text { interest }\end{array}$ & $\begin{array}{c}\text { Actual state and character } \\
\text { of the site }\end{array}$ & $\begin{array}{c}\text { Level of } \\
\text { preservation }\end{array}$ & $\begin{array}{l}\text { Plan for the } \\
\text { location }\end{array}$ \\
\hline \multirow{3}{*}{$\begin{array}{c}\text { Danube } \\
\text { industrial } \\
\text { zone }\end{array}$} & $\begin{array}{l}\text { Belgrade textile } \\
\text { factory }\end{array}$ & Reconstructed, occupied & $\begin{array}{l}\text { Complex under } \\
\text { previous protection }\end{array}$ & $\begin{array}{l}\text { Business } \\
\text { centre }\end{array}$ \\
\hline & $\begin{array}{c}\text { The "Power and Light" } \\
\text { Thermal Power } \\
\text { Station }\end{array}$ & $\begin{array}{l}\text { Devastated, very bad } \\
\text { condition, unoccupied, the } \\
\text { space is not in usable } \\
\text { condition }\end{array}$ & Cultural monument & Culture \\
\hline & $\begin{array}{c}\text { Kosta Sonda's } \\
\text { Confectionery Factory }\end{array}$ & Renovated and revitalized & Cultural monument & Hotel \\
\hline $\begin{array}{c}\text { Danube } \\
\text { industrial } \\
\text { zone }\end{array}$ & Klanica railway & $\begin{array}{l}\text { Devastated, very bad } \\
\text { condition }\end{array}$ & $\begin{array}{c}\text { No protection } \\
\text { measures have been } \\
\text { defined }\end{array}$ & \\
\hline
\end{tabular}

A theme entitled Line Park from Concrete Hall to Pančevo Bridge was opened on the Beobuild portal under the General Discussion section in April 2019. Until present, the topic has covered 157 posts on 7 pages. The participants in the discussion generally responded positively to the idea of realizing a large city park on this move, however, there were also those who advocated the retention of the railway. In addition, concerns were expressed regarding the current state of this space, as well as the possibility of removing existing temporary structures and warehouses. The current part of the discussion included some of the winning solutions, which were mostly positively responded to. The 
current part of the discussion included some of the winning solutions, which were mostly positively responded to, especially regarding the amount of greenery foreseen, but also the ways in which the strip was treated as an interpretation of the spirit of this place.

\section{CONCLUSION}

Although viewed as a kind of experiment, the approach used to reconstruct the trajectory of the former Slaughterhouse lane is an example of an expected practice in which co-creation and co-design lead to a common solution. That is why many positive reactions of citizens to the proposed competition solutions are not surprising, because they are just some kind of upgrade of the proposals made by themselves. In addition, there are clear roles in the whole process, including the role of urban planners and planners, as its mediators and coordinators, respecting the opinion of citizens and stakeholders, who in this case play the role of experts. In the coming period, we will witness how this well-conceived idea will be implemented.

\section{LITERATURE}

- Centar za eksperimente i urbane studije, 2019. Partrnerstvo za urbane inovacije. [Online] Available at: www.bellab.rs [Accessed April 2020].

_ Cizler, J., 2016. Aktiviranje napuštenih industrijskih objekata u gradovima: instutucionalna ograničenja u Srbiji (Activation of former industrial buildings in cities: institutional limitation in Serbia). Belgrade: University of Belgrade - Faculty of Architecure.

- Cvetinović, M., Nedović-Budić, Z. \& Bolay, J.-C., 2017. Decoding urban development dynamics through actor-network methodological approach. Geoforum, pp. 141-157.

_ Dajč, H., 2012. Uspon i degradacija Savskog priobalja. Limes Plus. Identitet Beograda, Issue 1-2, pp. 97-112.

- Maruna, M., 2015. Can Planning Solutions Be Evaluated without Insight into the Process of Their Creation?. Vienna, Real Corp, pp. 121-132.

_ Mihajlov, S., 2011. Nastanak i razvoj industrijske zone na desnoj obali Dunava u Beogradu od kraja 19. do sredine 20. veka (The origin and development of the industrial zone on the right bank of the Danube in Belgrade from the end of 19th to the midle of the 20th century). Nasleđe, Issue 12, pp. 91-116.

- Mučibabić, D., 2019. Novi park od Beton hale do Pančevačkog mosta. [Online]. Available at: http:// www.politika.rs/sr/clanak/427093/Novi-park-od-Beton-hale-do-Pancevackog-mosta [Accessed 10 April 2020].

_ Nikolić, M. and Roter Blagojević, M. 2018. "Potentialsof the Belgrade Industrial Heritage in the Context of Tourism Development". HERITAGE for PLANET EARTH, Proceedings ofthe 20th General Assembly of the International Experts of the Romualdo DelBianco Foundation (pp. 93-99). Florence: Romualdo DelBianco Foundation.

_ Nikolic, M, Drobnjak B. and Kuletin Culafic, I. 2020. "The Possibilities of Preservation, Regeneration and Presentation of Industrial Heritage: The Case of Old Mint "A.D." on Belgrade Riverfront." Sustainability 12 (13): 1-36.

_ Peric, A. \& Miljus, M., 2017. Spatial and Urban Planning in Serbia: A Look through the Lens of Deliberative Approach. Spatium, Issue 37, pp. 49-57.

_ Perić, A., 2016. The evolution of planning thought in Serbia: Can planning be 'resilient' to the transitional challenges?. Delft, TU Delft Open, pp. 181-193.

_ Riley, T. \& Gilbert Riley, C., 2003. E-Governance to E-Democracy: Examining the Evolution. [Online]. Available at: www.electronicgov.net/pubs/researchapers/tracking03/IntITrack Rpt June 03no5.pdf [Accessed April 2006].

_ Sokolova, M., 2006. Advocacy Democracy Modes: Benefits and Limitations. Informacijos Mokslai, Is- 
sue 36, pp. 110-121.

- Vujošević, M., 2010. Collapse of strategic thinking, research and governance in Serbia and possible role of the spatial plan of the Republic of Serbia. Spatium, Issue 23, pp. 22-29.

- Vukmirovic, M. \& Nikolic, M., 2021. Industrial Heritage Preservation and the Urban Revitalisation Process in Belgrade. Journal of Urban Affairs, pp. (accepted for publishing - in procedure).

- Vuksanović-Macura, Z., 2015. Bara Venecija i Savamala - železnica i grad (Bara Venecija and Savamala: The railway and the city. Nasleđe, Issue 16, pp. 9-26. 